\title{
THE CONCEPT OF STRUCTURE AND CONTENT OF HEALTH RELATED TRAININGS FOR HIGHER EDUCATIONAL ESTABLISHMENTS' STUDENTS
}

\author{
Kopylov Yu.A. ${ }^{1}$, Jackowska L.N. ${ }^{2}$, Kudryavtsev M.D. ${ }^{3}$, Kuzmin V.A. ${ }^{4}$, Tolstopyatov I.A. ${ }^{3}$, Iermakov S.S. ${ }^{5}$ \\ ${ }^{1}$ Institute of Developmental Physiology, Moscow, Russia \\ ${ }^{2}$ Siberian State Technological University, Krasnoyarsk, Russia \\ ${ }^{3}$ Siberian State Aerospace University, Krasnoyarsk, Russia \\ ${ }^{4}$ Siberian Federal University, Krasnoyarsk, Russia \\ ${ }^{5}$ Kazimierz Wielki University in Bydgoszcz, Bydgoszcz, Poland
}

\begin{abstract}
Purpose: analysis of modern directions of physical culture education scientific and practical problems' solution in higher educational establishment of health related orientation. Material: analysis of publications in scientific journals. Results: we have shown significance of student's physical functioning as the basis of his motor, coordination and mental qualities' development. Main difficulties of existing physical education practice have been cleared up. It has been found that prevailing training of physical qualities at physical culture classes does not solve the problem of students' health strengthening. Ways to application of additional health related physical culture trainings have been shown. Transition to such trainings opens opportunities for creation a new concept, permits to effectively and relatively quickly implement its main ideas and principles in practice of HEE education. Conclusions: content of additional (health related) physical culture training envisages prevailing orientation on health related, general developing and sport-recreational tasks. With it first attention shall be paid to formation of physical, psychic and social-moral health as well as to personality-oriented approach in system of individual choice of physical culture means.
\end{abstract}

Key words: students, health improvement, education, conception, trainings.

\section{Introduction}

Extremely unfavorable ecology, low level of healthy life style culture of higher educational establishments' students coincides with high social tension and uncertainty. It results in feeling of chronic anxiety, dissatisfaction, and loss of dynamic by social environment. In Russian Federation there is a steady trend to increasing of youth's morbidity [12]. Only for recent decade the quantity of weakened students has increased more than twice. Analysis of youth morbidity and physiological peculiarities of organism's development in ontogeny shows great importance of student's physical functioning. This functioning is the basis of motor, coordination and mental qualities of students [10, 25-30]. For higher educational school students the following if characteristic: restriction of motor functioning, worsening of physical qualities (strength, quickness, endurance, dexterity, flexibility), space orientation, vestibular stability, response to moving object, micro and macro motor qualities, visual motor responses [1]. In our country $70 \%$ of students do not practice physical culture. Prevalence of physical inactivity among students reached $80 \%$. Wrong and irrational eating resulted in body mass deficit in more than $30 \%$ of students. The same quantity of students has excessive weight. These and other deviations of health are the after effects of many reasons: reduction of motor functioning against the background of academic overloading. Quantity of physical culture lessons can not satisfy students' "motor hunger" [11]. Among reasons, which negatively influence on students' health, it is necessary to note: worsening of their life quality (worsening of life, work and leisure conditions, worsening of environment, quality and structure of eating); excessive stresses; decreasing of general culture (including hygienic one). All these are facilitated by spreading of harmful habits and unhealthy way of life.

The mentioned negative factors to large extent are connected with the fact that at previous historical stage physical culture (as part of general culture) was regarded mainly pragmatically. In its development it obeyed to perfection of "biological nature" of a person. Within the frames of this task physical culture lost its own social cultural forms and functions. It was seen as the process of mainly physical training. In HEE physical education

(C) Kopylov Yu.A., Jackowska L.N., Kudryavtsev M.D., Kuzmin V.A., Tolstopyatov I.A., Iermakov S.S., 2015 http://dx.doi.org/10.15561/20755279.2015.0504 
also solved the tasks of physical training. That is why by the present time a lot of scientific and practical problems have been accumulated:

- scientific-methodic elucidation of physical education principle reflects constantly existing dilemma in determination of functional orientation of physical culture as academic discipline: what shall be of priority biological or social development; accent on training of motor actions or cultivation of physical qualities; formation of demand in sport practicing or in independent practicing of physical culture;

- insufficiently developed age transition in students' mastering physical culture values. It determines orientation of practical methodic (first of all on "passport", partially on "biological" but not on "social" age);

- academic programs for students are discontinuous and fragmentary by content. Besides, they lack wholeness in its stage-by-stage mastering in different age periods; they are weakly oriented on development of cognitive and creative functioning of students;

- targeted orientation on students' fulfillment of physical training normative pre-sets the structure and content of physical culture classes as trainings. Such classes are characterized by the following: monotony of content, of used means and methods of pedagogic influence; increased volume of physical loads. Sometimes, it negatively impacts on students' functional state;

- strictly pre-set pedagogue's and curriculum's orientation on physical culture normative leaves the presence of students' individual value orientations and desires for practicing of health related physical exercises without attention. With it possibility of academic material reproduction in students' every day life, in organization of independent trainings is nearly not considered;

- there is observed worsening of students' health, increase of academic load and shortening of required scope of motor functioning. Health related physical culture measures within working day are used very seldom. Effectiveness of work with weakened students decreases. Differentiation of content of education, depending on health groups, is realized insufficiently;

- pedagogic practice of physical culture instructors has no target setting on students' active mastering of physical culture values. The sense of physical culture instructor's functioning if determined by development of physical qualities, required for fulfillment of norms and requirements of physical training. More correct orientation shall imply development of student's personality in combination with his (her) physical, psychic and social health.

All above said pre-determines demand in searching more effective forms of students' health improvement, increasing of their physical fitness. It should also be added that under existing practice of physical education these targets can hardly be achieved. In this connection transition to application of additional physical culture classes opens opportunities for creation of new concept; for effective and relatively quick implementation of its ideas and principles in practice of HEE education.

\section{Purpose, tasks of the work, material and methods}

The purpose of this work: is to substantiate analytically new approach to working out of content of physical culture additional trainings; analysis of new ways of health related physical culture application; determination of peculiarities of targeted usage of special exercises oriented on health strengthening and protection, on psychophysical trainings and self-training; searching of new effective directions of students' health stabilization and their individual health related functioning by interests.

\section{Results of the researches}

It is practically impossible to master the whole arsenal of possible student's and pupil's motor actions at standard physical culture lessons. Now there is principal opportunity to teach student to independently master different modifications of health related motor actions - rehabilitation exercises. This is connected with possibility of implementation of additional (health related-rehabilitation) physical culture trainings in curriculum of higher school [4]. Implementation of additional physical culture training is dictated by the following thoughts.

First - content of physical culture lesson and methodic of its conduct has reached their logical finish. Further improvement in this direction seems to be doubtful.

Second - academic overload of students, health disorders in different forms require rehabilitation measures. It is impossible at standard physical culture lessons (which overloaded with differently oriented tasks) or in system of health related physical culture [4]. 
It determined demand in introduction of new sector in physical education system - additional physical culture training of health related orientation. Implementation of additional culture training in academic process requires special development of its scientific methodic provisioning: structure and content of lesson; methodic of students' training to health related - rehabilitation exercises; system of control over progress (with realization of idea of "individual assessment scale"); regulation of loads.

Additional physical culture trainings with prevailing health related-rehabilitation orientation are built on the base of the following principles:

a) targeted and continuous character of health related exercises;

б) individual and address character of health related means;

в) combination of student's motor and mental progress.

Several approaches to composing of additional training's content can be marked out.

First approach: increasing of quantity of hours, assigned by main program for physical culture lessons.

Second approach: (also used for development of additional training's content) - application of the socalled "sport-like" principle, when students fulfill easy exercises under loads of low intensity.

Third approach: training of students to skills of independent fulfillment of health related exercises, which proved their effectiveness in improvement of organism's functional systems and control over emotional state.

Pedagogic process in frames of additional health related physical culture trainings is a holistic structure, which includes harmony of teaching, educational and training processes. Each of these structural components is characterized by its functional orientation as well as by content and its own technology of influencing on student's physical, psychic and emotional spheres:

- teaching - is realized through targeted transmission of social historic experience, accumulated in health related physical culture. It reflects in students' acquiring of appropriate knowledge and skills;

- education - is regarded as targeted impact of students' mind. It results in formation of students' settings and ideas of healthy life style, features of character and methods of interpersonal communication. воспитание рассматривается как целенаправленное воздействие на сознание студентов.

- training - is characterized by students' active mastering of principles of health related physical culture functioning as well as by formation of word vision in sphere of health related physical culture.

In conditions of additional physical culture training (oriented on mastering of meaning of health related physical culture functioning) there happens stage-by-stage development of student personality's physical culture:

- in special health group: identification - mastering of knowledge and means of physical culture functioning, mastering of movements and vitally important motor actions, health related physical exercises. It permits for student to actively enter in practicing of different forms of health related exercises;

-in preparatory health group: individualization is mastering and reproduction of knowledge, skills and motor actions in conditions of purposefully organized practicing of health related physical exercises. In this case, motor functioning is realized in compliance with combination of physical, psychic and moral qualities, acquired by students at previous stage of their personal progress;

- in main health group: actualization is mastering, reproduction and purposeful usage of means, methods and forms of organization of health related physical culture functioning as well as formation of own individual experience and creation of patterns and values, directly connected with satisfying of personal interests and demands.

In the frames of additional physical culture trainings health related physical culture activity has complex structural organization. It includes the following components: informational (knowledge), operational (means) and motivational (value patterns and orientations).

- Informational component combines knowledge about physical, psychic and social nature of person, about potentials of person's transformation in process of health related functioning;

- operational component includes means, methods and forms of functioning, methods of control over physical development, motor fitness, organism's functional state;

- motivation component includes patterns of movements and motor actions, ideas about forms of "physicality" and physical fitness levels, value orientations on satisfaction of socially significant, cultural and personal demands. 
One of important features of new approach to working out of content of physical culture additional trainings can be usage of main conceptual principles, oriented on interconnection of military-patriotic and physical education of pre-induction students [6]. Health related orientation of such trainings is saturated with specific material. It can permit to influence on organism's systems, which are often weakened in a student. With it, it is supposed to apply health related exercises, oriented not only on formation of physical health. Health is regarded as combination of physical, psychic and social components.

Health is not the goal of physical culture trainings. Physical culture is the most rational method of preparation fro works of different characters in compliance with individual interests of each student.

Main principles, determining requirements to formation of additional training's content in health related physical culture are as follows:

- cultural conformity, which reflects health related physical culture as social phenomenon as well as its connection with other forma and kinds of culture; as condition and result of student personality's development in unity of his (her) physical, mental and moral health's formation;

- personality's orientation is manifested in students' mastering physical exercises. It ensures cognition of individual peculiarities of organism's development and purposeful perfection of physical abilities. For example, it is very important to consider specific features of formation of students-boxers' socially significant qualities as the basis of future professional functioning [9];

- fundamental character, permitting to form students' world vision in the sphere of health related physical culture at every stage of additional training. It permits to open the sense of such relations as: nature culture; activity - labor; existence - progress and etc.;

- medical-biological and psychological-pedagogical periodization, which orients on correspondence of academic material to students' physical and mental potentials as well as on their health condition, age-gender features of individual development, dynamic of main physical qualities and interests to practicing of health related physical exercises;

- creativity, which creates possibility for students to develop their own individualized content of health related physical culture as well as personally oriented trainings and ability to practice such trainings independently.

The listed above principles reflect approaches to working out content of additional physical culture training. They permit to specify its purpose - formation of skills in usage of health related physical culture and purposeful special exercises' practicing for health protection and strengthening as well as for psycho-physical self training for studying and individual functioning by interests; for stabilization of students' health indicators.

\section{Discussion}

Prevailing training of physical qualities at physical culture lessons does not solve the problem of students' health strengthening, rising of their physical fitness [10, 13-18]. Avoiding of negative influences is possible under condition of students' involvement in physical culture functioning, in independently organized practicing of physical exercises. However, in existing practice of physical education this way is rather hampered because of the following:

- content of health related physical culture trainings (in their traditional forms) nearly does not consider students' demands, motives and value orientations; their individual potentials and abilities;

- program material of discipline physical culture does not ensure students' readiness to pass to independent organization of purposeful health related exercises' forms, as well as to use them for solution of personal, life and professionally oriented tasks and health improvement;

- physical culture instructors do not have proper competence in usage of new educational technologies; in mastering of individualized and non traditional, popular among modern students, physical exercises' systems; in new promising means, methods and forms of work with students.

The accumulated problems and contradictions of students' nowadays' education in the field of physical culture can not be solved only at the account of filling separate voids in existing system of physical education as well as they can not be solved by addition of new program material in discipline physical culture. These problems can be solved and shall be solved only on the base of creation of new theoretical conception. Such conception will become basic bench mark in development of HEE physical education. It will determine subsequent development of instructive normative, program-methodic and organizational-legal materials and documents. 
In this connection transition to application of additional physical culture training opens opportunities for creation of new concept and for effective and relatively quick implementation of its main ideas and principles in practice of HEE education. Analysis of school and HEE education vector by discipline "Physical culture" showed that up to the present time pupils and students have mastered "sport-like" skills in motor sphere. It was prevailing, final target and practically the only criterion of physical education effectiveness. Nowadays new bench mark appears. Pupils and students shall not learn "by heart" ready "patterns" of movements. They shall creatively understand them; supplement them in compliance with their individual features for solution of "motor" tasks in different non standard situations $[2,3,5]$.

\section{Conclusions}

Thus, content of additional (health related) physical culture training implies list of knowledge and skills. Prevailing orientation of such trainings shall be on solution of health related, general developing and sportrecreational tasks. With it first attention shall be paid to formation of physical, psychic and social-moral health as well as to personality-oriented approach in systems of individual choosing of physical culture means. Application of non traditional health related means will be highly effective in students' physical education [8].

It is important to use the principle of versatility. This principle permits to use knowledge and means of health related physical culture in different regions of country. It is oriented on students with different degree of physical culture literacy and fitness [7, 19-24]. It should be noted that opportunities for health related physical culture measures' conduct in specialized gyms and on sport sites are rather limited. In such cases additional health related physical culture trainings shall be conducted in autonomous conditions. For example in open sites, independent of their location, presence of simulators and sport apparatuses.

\section{Conflict of interests}

The authors declare that there is no conflict of interests. 


\section{References:}

1. Edeshko EI, Sadovskaia TN. Kompleksnaia sistema fizicheskogo vospitaniia studentov special'nykh medicinskikh grupp po nozologicheskim tipam zabolevanij [Complex system of physical education of special health groups' students by nosological types of diseases], Grodno: GSU; 2002. (in Russian)

2. Kudriavcev MD, Galimov GIa, Gas'kov AV. Obosnovanie effektivnosti uchebnykh zaniatij po fizicheskoj kul'ture s ozdorovitel'noj i obrazovatel'noj napravlennost'iu na osnove ocenki pokazatelej ispol'zovaniia elementov zdorovogo obraza zhizni [Substantiation of effectiveness of health related and educational physical culture trainings on the base of assessment of healthy life style elements' usage]. Vestnik Buriatskogo gosudarstvennogo universiteta. 2012;13:121-124. (in Russian)

3. Kudriavcev MD, Galimov GIa, Strel'nikov VA. Organizaciia fizkul'turno-obrazovatel'noj deiatel'nosti v razvivaiushchem obuchenii [Organization of physical culture-educational activity in developing teaching]. Vestnik Buriatskogo gosudarstvennogo universiteta. 2012;1:97-105. (in Russian)

4. Kudriavcev MD, Konoshenko LA, Goncharova VG, Miadelec TN. Sociokul'turnaia reabilitaciia lic s ogranichennymi vozmozhnostiami zdorov'ia [Social-cultural rehabilitation of disabled persons]. Zhurnal Sibirskogo Federal'nogo universiteta. Gumanitarnye nauki. 2013;6(4):555-561. (in Russian)

5. Kudriavcev MD, Galimov GIa. Ozdorovitel'naia napravlennost' uchebnykh zaniatij po fizicheskoj kul'ture [Health related orientation of academic physical culture lessons]. Vestnik Krasnoiarskogo gosudarstvennogo pedagogicheskogo universiteta. 2013;2:118-121. (in Russian)

6. Kudriavcev MD, Arutiunian TG, Galimov GIa, Gas'kov AV. Osnovnye konceptual'nye polozheniia izmenenij voenno-patrioticheskogo i fizicheskogo vospitaniia doprizyvnoj molodezhi [Main conceptual principles of changes in military-patriotic and physical education of pre-induction youth]. Vestnik Buriatskogo gosudarstvennogo universiteta. 2014;14:63-68. (in Russian)

7. Kuz'min VA, Kudriavcev MD, Galimov GIa, Kopylov IuA, Gas'kov AV. Sovremennye podkhody k sozdaniiu koncepcii i obnovleniiu struktury i soderzhaniia ozdorovitel'nogo fizicheskogo vospitaniia studentov vuzov [Modern approaches to creation of conception and renewal the structure and content of health related physical education of HEE students]. Vestnik Buriatskogo gosudarstvennogo universiteta. 2014;13:34-41. (in Russian)

8. Kuz'min VA, Kudriavcev MD, Galimov GIa, Kopylov IuA, Gas'kov AV. Effektivnost' ispol'zovaniia v sisteme fizicheskogo vospitaniia studentov netradicionnykh sredstv na primere khatkha-jogi [Effectiveness of non-traditional means' application in system of students' physical education on example of Hat ha Yoga]. Vestnik Buriatskogo gosudarstvennogo universiteta. 2014;13:41-44. (in Russian)

9. Kuz'min VA, Kudriavcev MD, Galimov GIa, Kopylov IuA, Gas'kov AV, Strel'nikov VA. Osobennosti formirovaniia social'no znachimykh lichnostnykh kachestv studentov-bokserov kak osnovy budushchej professional'noj deiatel'nosti [Peculiarities of formation of students-boxers' socially significant qualities as the basis of their future professional functioning]. Vestnik Buriatskogo gosudarstvennogo universiteta. 2014;13:68-72. (in Russian)

10. Morozova GS, Morozov SN. Organizaciia prakticheskikh zaniatij po fizicheskomu vospitaniiu studentov s oslablennym zdorov'em [Organization of practical classes on physical education for students with weakened health]. Mezhdunarodnaia nauchno-prakticheskaia konferenciia "Obrazovatel'naia, vospitatel'naia, razvivaiushchaia $i$ ozdorovitel'naia rol' fizicheskoj kul'tury $i$ sporta v VUZe». [International scientific-practical conference "Educational, cultivating and health related role of physical culture and sports in HEE"]. Moscow: RUND; 2006. (in Russian)

11. Timoshenko VV. Fizicheskoe vospitanie studentov i uchashchikhsia, imeiushchikh otklonenie v sostoianii zdorov'ia [Physical education of students and pupils, who have deviations in health], Minsk; 1995. (in Russian)

12. Shirkovec AIu. Fizicheskaia aktivnost' i vozrastnaia dinamika faktornoj struktury rabotosposobnosti [Physical activity and age dynamic of workability's factorial structure]. Teoriia i praktika fizicheskoj kul'tury. 2003;10:56 - 59. (in Russian) 
13. Balitskaya EP. Students' motivation to fitness classes at technical university. Pedagogics, psychology, medical-biological problems of physical training and sports, 2013;6:3-6. http://dx.doi.org/10.6084/m9.figshare.714933

14. Bazylyuk TA. Self-evaluation of health and interests of students of higher education institutions on course physical education. Pedagogics, psychology, medical-biological problems of physical training and sports, 2013;7:3-6. http://dx.doi.org/10.6084/m9.figshare.735943

15. Belykh SI. Dynamics of knowledge, skills and abilities in the process of personal physical education based university students. Pedagogics, psychology, medical-biological problems of physical training and sports, 2013;8:3-11. http://dx.doi.org/10.6084/m9.figshare.745776

16. Belykh SI. Structure of the concept of personality oriented physical education university students. Physical education of students, 2013;4:3-9. http://dx.doi.org/10.6084/m9.figshare.669663

17. Bukov UA, Eorgieva NG. The ways of teaching process optimization in physical education of the students' special medical group. Physical education of students, 2013;3:22-25. http://dx.doi.org/10.6084/m9.figshare.662536

18. Gordienko YV. Theoretical training in physical education of higher educational establishments' girl students. Physical education of students. 2015;4:3-9. http://dx.doi.org/10.15561/20755279.2015.0401

19. Iermakov SS, Apanasenko GL, Bondarenko TV, Prasol SD. Physical culture is a basic instrument of culture of health // Pedagogics, psychology, medical-biological problems of physical training and sports, 2010;11:31-33.

20. Iermakov SS, Ivashchenko PI, Guzov VV. Features of motivation of students to application of individual programs of physical self-preparation // Physical education of students. 2012;4:59 - 61.

21. Klimatskaya LG. Physical activity students and university professors as leaders of health. Physical education of students, 2013;3:31-34. http://dx.doi.org/10.6084/m9.figshare.669673

22. Kovaleva MV, Rumba OG. Active games in physical education students of special medical group with limited capacity of cardiovascular system. Physical education of students, 2013;4:35-45. http://dx.doi.org/10.6084/m9.figshare.68164

23. Kozina ZL, Iermakov SS. Analysis of students' nervous system's typological properties, in aspect of response to extreme situation, with the help of multi-dimensional analysis. Physical education of students. 2015;3:10-19. http://dx.doi.org/10.15561/20755279.2015.0302

24. Kramida IE. Exercises for students of different medical groups as factors of the weakening bad habits at students. Physical education of students, 2013;4:46-50. http://dx.doi.org/10.6084/m9.figshare.669680

25. Lukianova YuS. School health approach to teaching and learning of students. Pedagogics, psychology, medical-biological problems of physical training and sports, 2015;1:52-56. http://dx.doi.org/10.15561/18189172.2015.0110

26. Pichurin VV. Coping strategies and psychological readiness of students for professional work. Pedagogics, psychology, medical-biological problems of physical training and sports. 2015;2:53-59. http://dx.doi.org/10.15561/18189172.2015.0209

27. Pivneva MM, Rumba OG. Aerobics health as means of increasing somatic health of students of special medical group. Pedagogics, psychology, medical-biological problems of physical training and sports, 2013;8:74-87. http://dx.doi.org/10.6084/m9.figshare.747477

28. Prusik Krzysztof, Prusik Katarzyna, Kozina ZhL, Iermakov SS. Features of physical development, physical preparedness and functional state of boys and girls - students of Polish higher educational establishments. Physical education of $\quad$ students, 2013;1:54-61. http://dx.doi.org/10.6084/m9.figshare.96415

29. Roters TT. Physical improvement of students during interactive physical and aesthetic education. Physical education of students, 2013;4:72-76. http://dx.doi.org/10.6084/m9.figshare.663624

30. Yurchyshyn YV. Modern information tools: their place in students' extra-curriculum and involvement of them in motor activity of health related orientation. Physical education of students. 2015;4:44-50. http://dx.doi.org/10.15561/20755279.2015.0407 


\section{Information about the authors: \\ Kopylov Yu.A.; http://orcid.org/0000-0002-3925-0483; yuko.47@mail.ru; Institute of Developmental Physiology Pogodinskaya st., 8, k. 2, Moscow, 119869, Russia.}

Jackowska L.N.; http://orcid.org/0000-0002-2432-1699; kumid@yandex.ru; Siberian State Technological University st. Markovski, 57, Krasnoyarsk, 660049, Russia.

Kudryavtsev M.D.; http://orcid.org/0000-0002-4377-0879; kumid@yandex.ru; Siberian State Aerospace University; Office A-406, 31, Krasnoyarsky Rabochy Av., 660014, Krasnoyarsk, Russia.

Kuzmin V.A.; http://orcid.org/0000-0002-4190-1628; atosn35@mail.ru; Siberian Federal University; 79 Svobodny pr., Krasnoyarsk, 660041, Russia.

Tolstopyatov I.A.; http://orcid.org/0000-0001-9556-0577; tia965@mail.ru; Siberian State Aerospace University; Office A406, 31, Krasnoyarsky Rabochy Av., 660014, Krasnoyarsk, Russia.

lermakov S.S.; http://orcid.org/0000-0002-5039-4517; sportart@gmail.com; Kazimierz Wielki University in Bydgoszcz; Chodkiewicza str. 30, 85-064 Bydgoszcz, Poland.

Cite this article as: Kopylov Yu.A., Jackowska L.N., Kudryavtsev M.D., Kuzmin V.A., Tolstopyatov I.A., Iermakov S. S. The concept of structure and content of health related trainings for higher educational establishments' students. Physical education of students, 2015;5:23-30. http://dx.doi.org/10.15561/20755279.2015.0504

The electronic version of this article is the complete one and can be found online at: http://www.sportpedu.org.ua/html/arhive-e.html

This is an Open Access article distributed under the terms of the Creative Commons Attribution License, which permits unrestricted use, distribution, and reproduction in any medium, provided the original work is properly cited (http://creativecommons.org/licenses/by/4.0/deed.en).

Received: 16.08 .2015

Accepted: 29.08.2015; Published: 02.09.2015 